\title{
Rising seas and retreating coastlines
}

\author{
Roshanka Ranasinghe • Marcel J. F. Stive
}

Received: 26 August 2008 / Accepted: 13 March 2009 / Published online: 16 May 2009

(C) The Author(s) 2009. This article is published with open access at Springerlink.com

Any rise in the mean sea level will result in the retreat of unprotected coastlines (Bruun 1962). Fortunately, the still-stand (slow) conditions of global average sea level rise (SLR) during the last century has resulted in slow and mostly manageable coastline retreat (recession). Alarmingly, however, recent research indicates that the global average sea levels may rise at an unprecedented rate during the twenty-first century (Leuliette et al. 2004; Beckley et al. 2007). The latest IPCC projections (IPCC 2007) indicate an SLR range from 0.18 to $0.79 \mathrm{~m}$ by 2090-2099 relative to 19801999 , including an allowance of $0.2 \mathrm{~m}$ for uncertainty associated with ice sheet flow. Very recent research (Rahmstorf et al. 2007) also suggests that the measured SLR over the last decade was following the upper range SLR projections given in the IPCC Third Assessment Report (TAR) and the IPCC Fourth Assessment Report (AR4) (Note: The upper range TAR projections are very close to the upper range AR4 projections when the ice sheet contributions are considered). Furthermore, Rhamstorf (Rahmstorf 2007) suggests that higher SLR rates than those projected by IPCC TAR and AR4 may also be possible. In comparison, the global average rate of SLR during the twentieth century was 1-2 mm/year (Church and White 2006; Douglas et al. 2000). This means that the SLR during the twenty-first century could be as much as eight times higher than that during the last century, which in turn is likely to result in much faster coastline recession in the twenty-first century. The socio-economic impact of such accelerated coastal recession could be massive due to the unprecedented growth of coastal communities over the last 50 years or so which has led to $\$$ billions worth of developments and infrastructure within the coastal zone. To ensure the safety of growing coastal communities and to avoid massive economic

R. Ranasinghe $(\bowtie)$ · M. J. F. Stive

Department of Hydraulic Engineering, Delft University of Technology,

PO Box 5048, 2600 GA, Delft, The Netherlands

e-mail: R.Ranasinghe@unesco-ihe.org

R. Ranasinghe

Department of Water Engineering, UNESCO-IHE,

PO Box 3015, 2601 DA, Delft, The Netherlands 
losses in the future, predictions of coastal recession due to SLR need to be highly accurate; now more so than ever before.

Although its usefulness as a predictive tool has been a controversial issue for decades (Pilkey and Cooper 2004; Nicholls and Stive 2004; Nicholls et al. 2007; Cooper and Pilkey 2004), the method most commonly used to estimate coastal recession due to SLR is the simple two dimensional mass conservation principle known as the Bruun Rule (Bruun 1962). Essentially, the Bruun Rule predicts a landward and upward displacement of the cross-shore sea bed profile in response to a rise in the mean sea level and is expressed as:

$$
R=L S /(B+h)
$$

where, $h=$ the maximum depth of exchange of material between nearshore and offshore, $L=$ horizontal distance from the shoreline to depth $h, B=$ berm or dune elevation estimate for the eroded area, $S=$ sea level rise, and $R=$ horizontal extent of coastal recession.

Thus, the Bruun Rule predicts that the recession $(R)$ is simply equal to the quantity of SLR $(S)$ divided by the slope of the active nearshore bed profile $((B+$ $h) / L$ ). Due to its simplicity and the lack of any easy-to-use alternative methods, coastal scientists and engineers have been routinely using the Bruun Rule for almost five decades. However, in view of the projected future acceleration in SLR, can we continue to depend on the Bruun rule for predictions of future coastal recession? This question is now more relevant than ever, particularly in view of the high level of predictive accuracy that is clearly needed to avoid massive socio-economic losses in the twenty-first century and beyond.

Any effective predictive method needs to satisfy two essential criteria: (a) it should be widely applicable, and (b) it should produce highly accurate and reliable predictions. On the first criterion, the applicability of the Bruun Rule is severely restricted due to its many underlying assumptions. The main assumption of the Bruun Rule is that all sand transport occurs perpendicularly to the shoreline (i.e. crossshore), which makes it a strictly two-dimensional model. Thus, the Bruun rule does not accommodate any three-dimensional variability that is common along natural coastlines, precluding its application in areas adjacent to headlands or engineering structures, lagoon and estuary inlets, deltas and other areas with significant gradients in alongshore sediment transport. This lack of general applicability of the Bruun rule was amply illustrated in a recent large scale study of coastal recession along a $220 \mathrm{~km}$ stretch of the US East coast, where almost $70 \%$ of the study area was excluded from the analysis to eliminate the influence of the many inlets and engineering structures in the study area (Zhang et al. 2004). The other assumptions associated with the Bruun Rule (e.g. applicable only along an equilibrium profile, uniform sediment size along profile) also place significant limitations on its general applicability.

On the second essential criterion of predictive accuracy, the two input parameters to the Bruun Rule are: a) the quantity of sea level rise $(S)$, and b) slope of the active nearshore bed profile $(\tan \beta=(B+h) / L)$. According to latest projections, the global average sea level rise by 2100 (relative to 1990 levels) could be anywhere between $18 \mathrm{~cm}$ and $1.4 \mathrm{~m}$ (IPCC 2007; Rahmstorf 2007). This uncertainty alone would produce Bruun Rule recession estimates that could vary by about $700 \%$. The second input parameter, the slope of the active profile, is largely governed by ' $h$ ' (i.e. depth of closure DoC). Due to the general dearth of field information 
at many coastal locations, it is common practice to use one of the many available empirical formulations to estimate the DoC. However, depending on which DoC formulation is used, the estimated DoC, and thus the slope of the active profile $(\tan \beta$ can vary significantly. For example, the application of four widely used DoC theories at Sydney, Australia resulted in active profile slope estimates ranging from 0.0625 (one in 16) to 0.011 (one in 91; Ranasinghe et al. 2007). This uncertainty range in $\tan \beta$ alone would produce Bruun rule recession estimates that could vary by about $500 \%$. When the uncertainties of both $S$ and $\tan \beta$ are combined, the Bruun rule recession estimates for Sydney range between $3 \mathrm{~m}$ and $127 \mathrm{~m}$; this is a potential variability of $4,000 \%$ in predictions! Such a high variability in predictions raises significant concern regarding the quantitative accuracy and robustness of Bruun rule predictions. It is noted, however, that the uncertainty inherent in the IPCC SLR projections (due to model and scenario uncertainty) will be unavoidable even if a more sophisticated method were to be used to predict SLR driven coastal recession.

Furthermore, while the many attempts over the last four decades to verify the Bruun Rule against field and laboratory data (e.g. Hands 1983; Rosen 1978; Everts 1985; Pilkey and Davis 1987; Dean 1990) have qualitatively confirmed the basic concept of the Bruun Rule, very few have resulted in convincing quantitative comparisons between measurements and Bruun Rule predictions of coastal recession due to global average SLR (SCOR Working Group 89 1991; Stive 2004). In any case, under present stillstand sea level rise conditions, coastal recession due to SLR alone can be significantly masked/enhanced by accretion/erosion due to other processes such as offshore sediment losses during storms, aeolian transport, backbarrier infilling and alongshore gradients in longshore transport (Stive 2004). Thus, it would indeed be very difficult to comprehensively verify the quantitative accuracy of Bruun rule predictions of SLR driven coastal recession under present SLR conditions.

In essence therefore, the high level of uncertainty associated with Bruun Rule predictions and the lack of comprehensive verification of the method renders it generally unsuitable for the purpose of obtaining exact and site specific predictions of coastal recession due to SLR, particularly in view of the accelerated SLR projected for the twenty-first century. At best, any predictions obtained via the Bruun rule should be considered only as broadly indicative estimates that are not suitable for direct use in coastal planning and management. A robust solution to the problem lies in comprehensive bottom-up (small-scale, process-based) and top-down (large-scale, behavior-based) numerical models. Once comprehensively validated by field data, such numerical models can be strategically applied to determine quantitative forcingresponse relationships of complex, non-linear coastal processes. These relationships can then be aggregated and/or parameterized and embedded into a robust and easyto-use numerical model which accounts for at least the primary physical processes governing coastal recession. Such a process based approach, especially when used within a probabilistic simulation method, would constitute a significant step forward from a standard Bruun Rule application and is likely to provide more scientifically robust predictions of SLR driven coastal recession that can be reliably adopted in coastal management and planning.

Acknowledgements The first author is extremely grateful to Phil Watson (DECC, NSW, Australia) for the many inspiring discussions regarding the application of the Bruun Rule in coastal management, which essentially led to this manuscript. David Callaghan (University of Queensland) and Judith Bosboom (Technical University of Delft, The Netherlands) are also acknowledged for the 
many long discussions on the subject and for their constructive criticisms of the manuscript. The views expressed are those of the authors and do not necessarily reflect the views of the organisations they are affiliated to.

Open Access This article is distributed under the terms of the Creative Commons Attribution Noncommercial License which permits any noncommercial use, distribution, and reproduction in any medium, provided the original author(s) and source are credited.

\section{References}

Beckley BD, Lemoine FG, Luthcke SB, Ray RD, Zelensky NP (2007) A reassessment of global and regional mean sea level trends from TOPEX and Jason-1 altimetry based on revised reference frame and orbits. Geophys Res Lett 34:L14608

Bruun P (1962) Sea level rise as a cause of shore erosion. J Waterw Harb Div 88:117

Church JA, White NJ (2006) A 20th century acceleration in global sea level rise. Geophys Res Lett 33:L01602

Cooper JAG, Pilkey OH (2004) Sea level rise and shoreline retreat: time to abandon the Bruun rule. Glob Planet Change 43:157

Dean RG (1990) Beach response to sea level change. In: LeMehaute B, Hanes DM (eds) The sea, vol 9. Wiley, New York, pp 869-887

Douglas BC, Kearney MS, Leatherman SP (2000) Sea level rise: history and consequences. Academic, San Diego

Everts CH (1985) Sea level rise effects on shoreline position. J Waterw Port Coast Ocean Eng 111(6):985

Hands EB (1983) The great lakes as a test model for profile responses to sea level changes. In: Komar PD (ed) Handbook of coastal processes and erosion. CRC, Boca Raton, pp 176-189

IPCC (2007) Contribution of working group I to the fourth assessment report of the intergovernmental panel on climate change. Summary for Policymakers, $18 \mathrm{pp}$

Leuliette EW, Nerem RS, Mitchum GT (2004) Calibration of TOPEX/Poseidon and Jason altimeter data to construct a continuous record of mean sea level change. Mar Geod 27:79

Nicholls RJ, Stive MJF (2004) Society and sea level rise requires modelling. Sci E-letters 303:5665

Nicholls RJ, Wong PP, Burkett VR, Codignotto JO, Hay JE, McLean RF, Ragoonaden S, Woodroffe CD (2007) Coastal systems and low-lying areas. In: Climate change 2007: impacts, adaptation and vulnerability. Contribution of working group II to the fourth assessment report of the intergovernmental panel on climate change. Cambridge University Press, Cambridge, UK

Pilkey OH, Cooper JAG (2004) Society and sea level rise. Science 303:1781

Pilkey OH, Davis TW (1987) An analysis of coastal recession models: North Carolina coast. In: Nummedal D, Pilkey OH, Howard JD (eds) Sea-level fluctuation and coastal evolution. SEPM (Society for Sedimentary Geology) Special Publication No. 41, Tulsa, Oklahoma, pp 59-68

Rahmstorf S (2007) A semi-empirical approach to projecting future sea-level rise. Science 315:368

Rahmstorf S, Cazanave A, Church J, Hansen J, Keeling R, Parker D, Somerville R (2007) Recent climate observations compared to projections. Science 316:709

Ranasinghe R, Watson P, Lord D, Hanslow D, Cowell P (2007) Sea level rise, coastal recession and the Bruun rule. In: Proc. coasts and ports' 07. Engineers Australia (on CD ROM)

Rosen P (1978) A regional test of the Bruun rule on shoreline erosion. Mar Geol 26:M7

SCOR Working Group 89 (1991) The response of beaches to sea-level changes: a review of predictive models. J Coast Res 7(3):895

Stive MJF (2004) How important is global warming for coastal erosion? Clim Change 64:27 (editorial comment)

Zhang K, Douglas BC, Leatherman SP (2004) Global warming and coastal erosion. Clim Change 64:41 